\title{
Morphometric Analysis of Didessa River Catchment in Blue Nile Basin, Western Ethiopia
}

\author{
Tesfaye Muluneh ${ }^{*}$ and Wondimu Mamo
}

Department of Geography and Environmental Studies, Wollega University, Gimbi, Ethiopia

\begin{tabular}{ll} 
Abstract & Article Information \\
\hline In the present paper an attempt has been made to study the morphometric characteristics of & Article History: \\
Didessa catchment which is part of Blue Nile River basin located in South Western part of & Received : 14-06-2014 \\
Ethiopia. The study focused on evaluating the effect of morphometric parameters on the & Revised $: 21-09-2014$ \\
hydrology and morphology of the basin. The primary data for this study was an elevation data & Accepted : 26-09-2014 \\
\cline { 2 - 2 } in raster format (Digital Elevation Model or DEM) also known as ASTER DEM of 30m spatial & Keywords: \\
resolution. Stream networks and watersheds were delineated in ArcGIS 10.1 software & ASTER DEM \\
environment by utilizing ArcHydro and Spatial Analyst Tools. Based on the results of the & ArcHydro \\
software analysis, linear, areal, and relief aspects of the basin were computed. The result & Hydrology \\
indicates that Geo-spatial techniques and DEMs data are efficient for extracting stream & Watershed \\
\cline { 2 - 2 } networks and characterizing the morphology of watersheds as well as computing the various & Tesfaye Mulung Author: \\
indices of drainage basin morphometry. Hence, the results of this study provide useful inputs & E-mail: \\
for watershed level planning and management. & tesfaye.m@hotmail.com \\
Copyright@2014 STAR Journal. All Rights Reserved. & \\
\hline
\end{tabular}

\section{INTRODUCTION}

Drainage basin, also known as catchment or watershed is a finite part of the landform whose runoff is channeled through a single outlet. Morphometry is a means by which the various spatial characteristics of a drainage basin is quantitatively described (Pidwimy, 2006). The most common drainage basin parameters fall under classes of linear, areal, and relief variables and include number, length, density and bifurcation of streams/ rivers as well as shape, area, relief and gradient of the basin.

The foundations for recovering the various drainage characteristics that involve both the spatial and numerical variables from topographic maps have been laid down by (Horton, 1945; Miller, 1953; Strahler, 1952). In recent decades, however, advancement in geospatial technology has brought fundamental transformations in both the data used and methodology of extracting the essentials drainage basin characteristics. With regard to data, DEMs (Digital Elevation Models) and images of the Earth's surface obtained from remote sensing systems have proved more useful in terms of flexibility and accuracy than that of topographic maps, whereas software/application based spatial analysis methods such as GIS (Geographic Information System) has become the state-of-the art technology for efficiently delineating drainage basins and extracting watershed properties as well as computing the various indices of drainage morphometry. (Mason, 2000; Gopalan, Whiteaker, and Maidment, 2003; Romshoo, Bhat, and Rashid, 2012; Lima and Correa, 2011).
Morphometric analysis of river catchments is essential for investigating the development potential of land and water resources of a given region. In specific terms, results of river morphometric analysis yield useful information pertinent to the ruggedness of the terrain, irrigation potential of the basin, flood risks control and above all, it provides an input for understanding the role of the physical characteristics of the terrain in development of the drainage basin (Vandana, 2012).

A number of studies have utilized the technique of Geographical Information System and digital elevation models for numerically and qualitatively describing the spatial characteristics of drainage basins that are applicable for statistical, comparative and analytical analyses. An evaluative study has been carried out by (Mason, 2000) in which he assessed the methodology of analyzing watershed parameters using GIS. In this study he concluded that GIS is an effective method and DEMs are accurate source of terrain information. According to Maidment (2002), the advent of DEMs has resulted in the evolution of procedures to automatically map or derive channel networks and water sheds from DEMs. Gopalan, et al., (2003) also analyzed the effectiveness of specific GIS tools such as ArcHydro in the study of basin parameters. A study by (Mason, 2000) has shown that a higher resolution data (i.e. smaller grid spacing of at least $30 \mathrm{~m}$ ) could accurately represents the drainage features of the terrain and results in more accurate watershed delineations. 
Tesfaye Muluneh and Wondimu Mamo

Following these studies several scholars have applied the techniques in characterizing drainage basin (Chrisopher et al., 2010; LIMA and CORREA, 2011; Vandana, 2012; Romshoo et al, 2012; Patino et al., 2003) are some of the latest among such studies. Studies of drainage basins using DEM data and geo - information technologies is almost nonexistent in the case of Ethiopia. The current study is therefore aimed at using DEMs as basic data model and utilizing of GIS for watershed delineation, involving the extraction of hydrologic information from digital elevation models(DEMs) so as to characterize the Didessa river basin.

\section{MATERIALS AND METHODS Study Area}

The Didessa river basin is geographically located between $07^{\circ} 40^{\prime} \mathrm{N}$ and $10^{\circ} 00^{\prime} \mathrm{N}$ - Latitude and $35^{\circ} 30^{\prime} \mathrm{E}$ $37^{\circ} 15^{\prime} \mathrm{E}$ Longitude. The general elevation in the basin ranges between 612 meter a.m.s.l. and 3,200 meter a.m.s.l. Physically, Didessa basin drains four zones (Jima, Illubabor, East Wollega, and West Wollega) of the National Regional State of Oromia as well as Benishangul Regional State.

Didessa River, which is the largest tributary of the Blue Nile (Abay) contributes roughly a quarter of the total flow of Blue Nile. The total catchment area drained by the river is estimated to be $27,000 \mathrm{~km}^{2}$ originating from the mountain ranges of Gomma in South Western Ethiopia. The main upper streams namely; Temsa and Yebbu rivers in the South flow eastwards for about $75 \mathrm{kms}$ until they are joined by the Eastern tributaries such as Wama, Indris and so on, then after, turning rather sharply to the north until it reaches the Blue Nile (Abay) River. In the North East direction, the main tributary of Didessa River with the largest catchment area is Anger River (Figure 1).

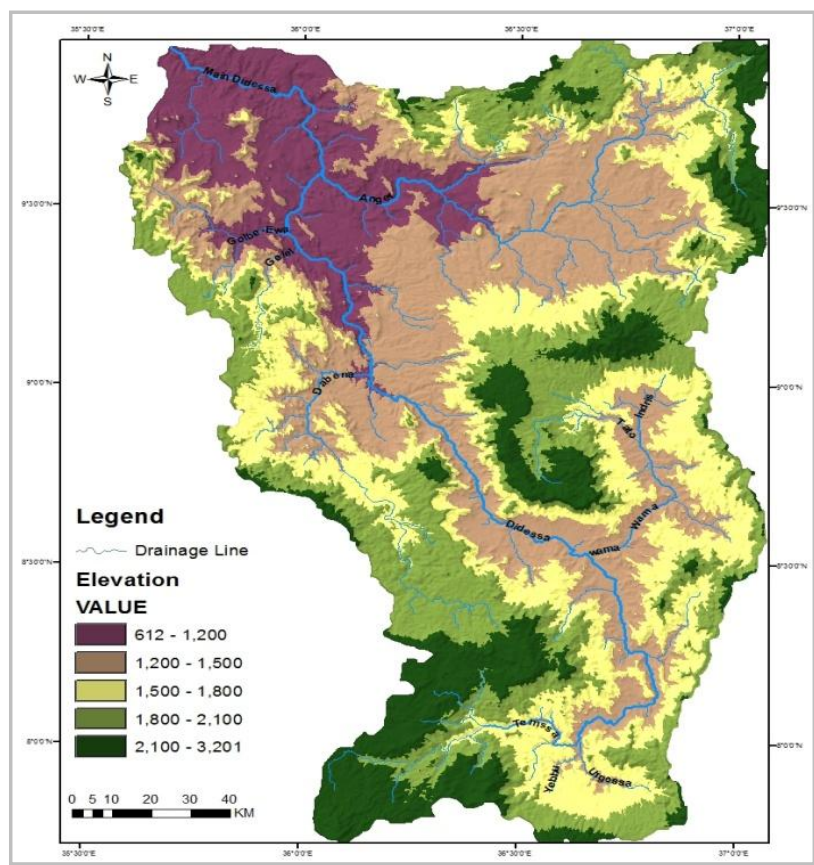

Figure 1: Map of the study area

The primary data for this study is an elevation data in raster format (digital elevation models or DEMs) which was obtained from remote sensing instrument known as Advanced Space-borne Thermal Emission and Reflection Radiometer (ASTER) attached on a satellite platform,
Sci. Technol. Arts Res. J., July-Sep 2014, 3(3): 191-197

SRTM (Shuttle Radar Topography Mission). A DEM is a grid of cells in some coordinate system having land surface elevation as the value stored in each cell. DEMs are derived from elevation samples collected at varying spatial units or cell sizes. Thus, DEMs have varying spatial resolution based on their sampling levels.

Spatial resolution (also known as grid spacing) is one of the main factors that affect the accuracy of a DEM. For this study 30m DEM with grid cells of 1 by 1 arc-second spacing or elevation values at 30-meter intervals obtained from ASTER GDEM Distribution site; (http://gdem.ersdac.jspacesystems.or.jp/search.jsp) was utilized.

The 1 by 1 arc-second grid data (DEM) for the study area was mosaicked together using Exelis ${ }^{\circledR}$ ENVI 5.0 (Environment for Visualizing Images) software. Stream networks and catchments were delineated in ESRI's ArcGIS 10.1 Environment using ArcHydro and Spatial Analyst tools. The following flowchart is adopted in this study for the process of extracting hydrologic information, such as basin boundaries and stream networks, from a digital elevation model (DEM).

\section{RESULTS AND DISCUSSION}

The present study utilized Geographic Information System's Spatial Analysis and Hydrology functions along with remote sensing in order to drive stream networks and delineate river catchments from DEM. The morphometric analysis and linear, areal, and relief values and indexes were determined and discussed as follows. Some of the formulae employed in the present study are given in Table 2 , and the results are summarized in Table 2 and figures along with brief descriptions.

\section{i) Drainage Network}

The linear properties of drainage basin computed include stream order, stream length, mean stream length, bifurcation ratio, and the results of the analysis are shown in Table-1 and discussed as follows.

\section{Stream Order $\left(S_{u}\right)$}

Arranging streams in their order precedes all the processes of computations of morphometric parameters of drainage basins. Streams may be categorized according to their position-order or magnitude-within a drainage network. Stream order can be used to describe a stream and to conveniently divide a stream network into component parts that may be quantified and compared. According to Strahler (1957b), streams that do not possess a tributary are designated as first order streams. Second order streams are formed at the junction of first order streams, and it follows that stream order increases when two streams of the same order join. The number and length of first order streams in a basin can be measured and compared to those in a separate basin.

Accordingly, the order of streams and their corresponding numbers, and stream length of the four watershed are counted and presented in Table 1. It has been computed that Dabena-Didessa watershed is of $6^{\text {th }}$ order, while the remaining three watersheds, namely; Anger, Wama, and Yebbu-Temssa are of $5^{\text {th }}$ order watersheds. Based on Horton's Law (1945) cited in Strahler (1957b), the number of streams is related in an inverse geometric sequence with order number and this is shown graphically as in Figure 1. 
Tesfaye Muluneh and Wondimu Mamo

\section{Stream Number $\left(N_{u}\right)$}

The total number of streams of each order in a watershed is known as stream number. Based on Horton (1945), there is an inverse relationship between the number of streams and their order number (Figure 1). The number of $1^{\text {st }}$ order streams in a basin is dependent upon a variety of climatic, geologic, and hydrologic factors. Holding all other variables constant drainage basin in an
Sci. Technol. Arts Res. J., July-Sep 2014, 3(3): 191-197 arid climate would have more first order streams than a watershed in a more humid climate.

\section{Stream Length $\left(L_{u}\right)$}

Stream length is the ground length of the flow path of all streams of each order. This is computed by ArcGIS software and the relationship between total stream length and the corresponding stream order is also an inverse as shown by Figure 3 .

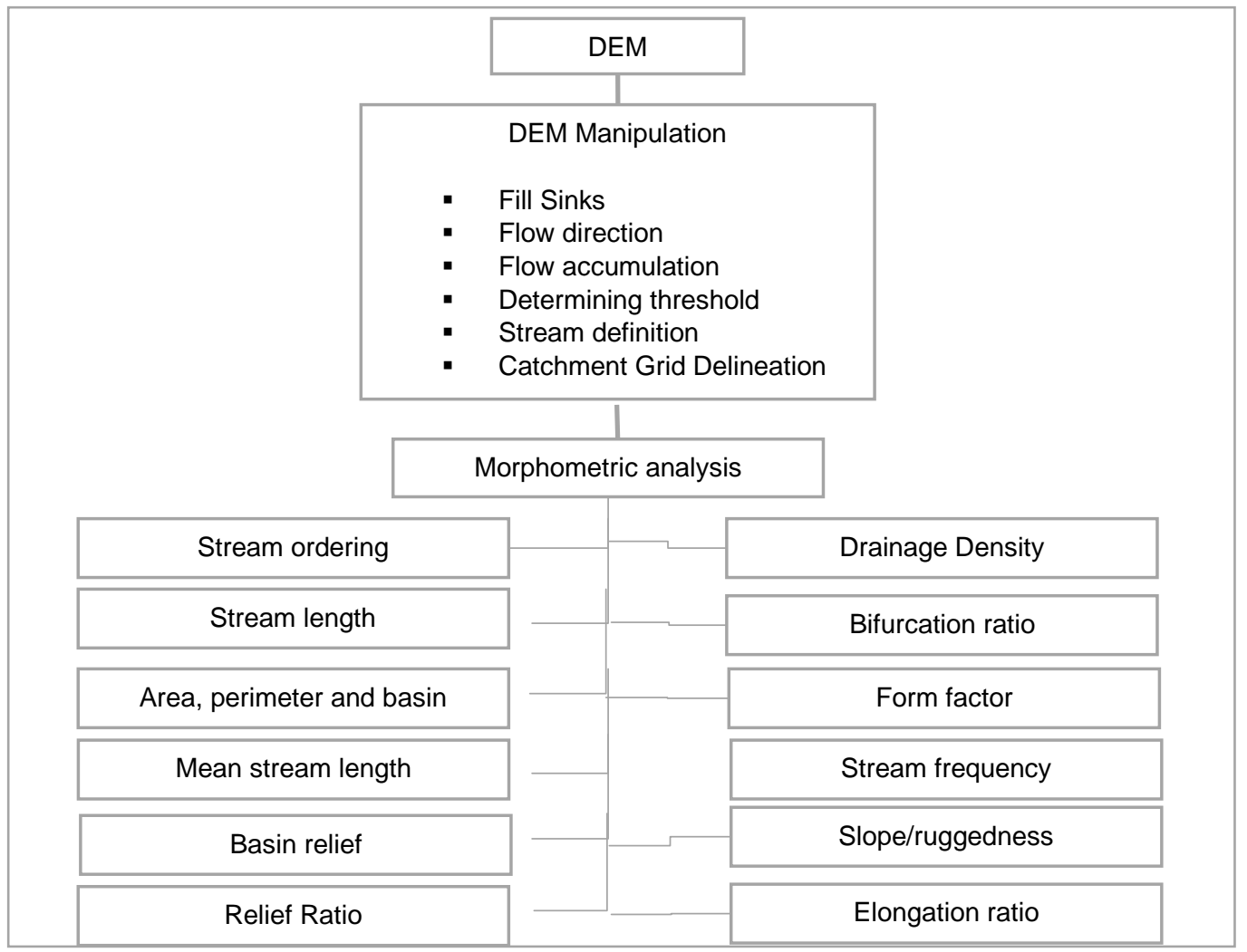

Figure 2: Stream delineation and morphometric analysis flow chart

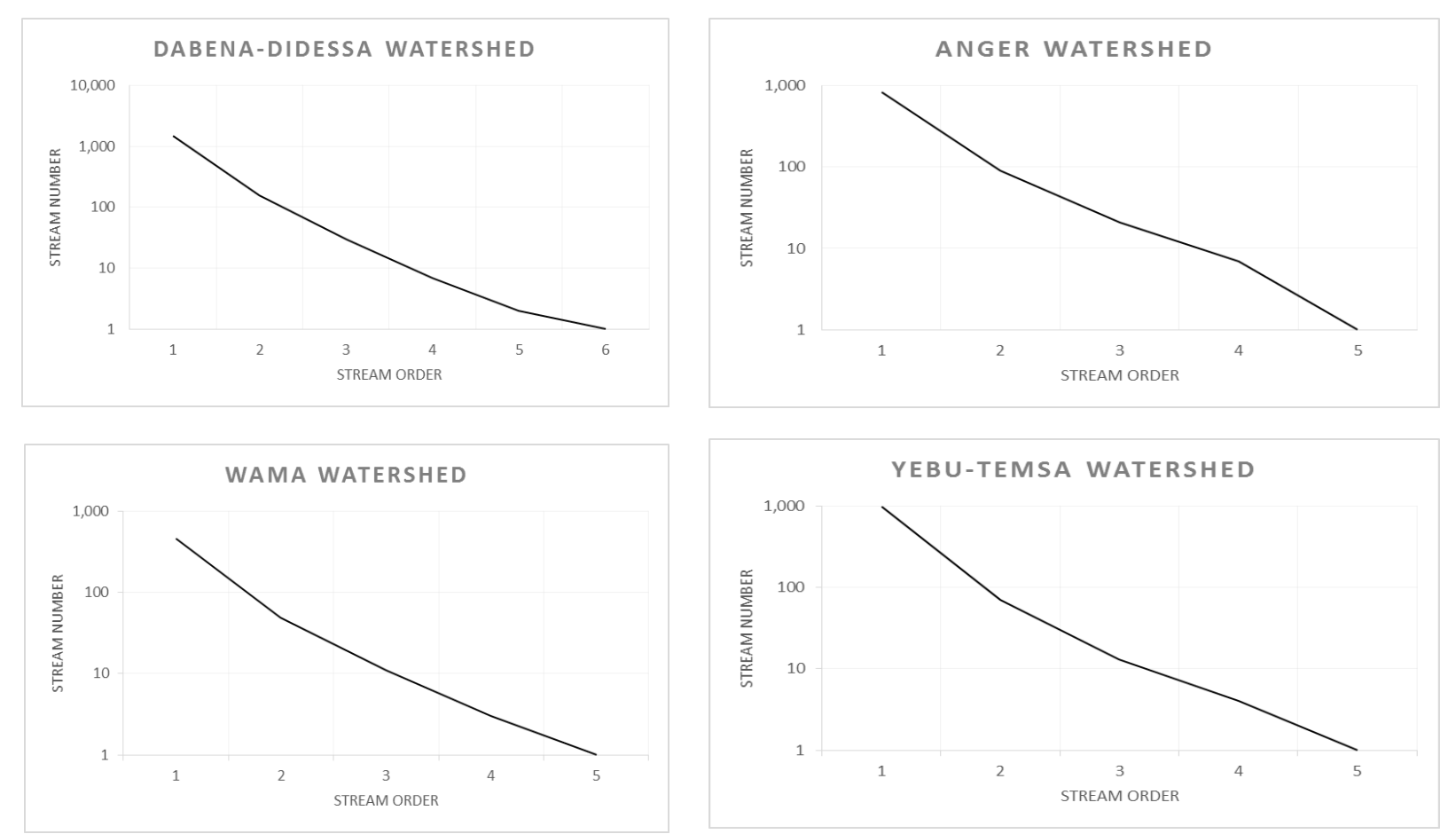

Figure 3: Log plots of stream order versus stream number 


\section{Tesfaye Muluneh and Wondimu Mamo}

Stream length is a good indicator of the topography of the land surface. In areas of steep slopes, the length of streams are shorter. An anomaly has been detected in Dabena-Didessa, watershed where the length of a single $6^{\text {th }}$ order stream is about $263.58 \mathrm{~km}$. This means, there is low gradients for sufficiently long distance in this watershed. Moreover, draining longer distance without a change in order enable streams to slowly accumulate large volume of water because with increasing distance,
Sci. Technol. Arts Res. J., July-Sep 2014, 3(3): 191-197 the size of the contributing area also increases. (Table 1 and Figure 5).

\section{Mean Stream Length $\left(\bar{L}_{u}\right)$}

Mean stream length shows the relationship between drainage network and size of the contributing area (Strahler, 1964). $\bar{L}_{u}$ is computed by dividing the total length of stream of an order by the total number of streams in the order. Table 1 shows the mean stream length of all order streams for the four watersheds.
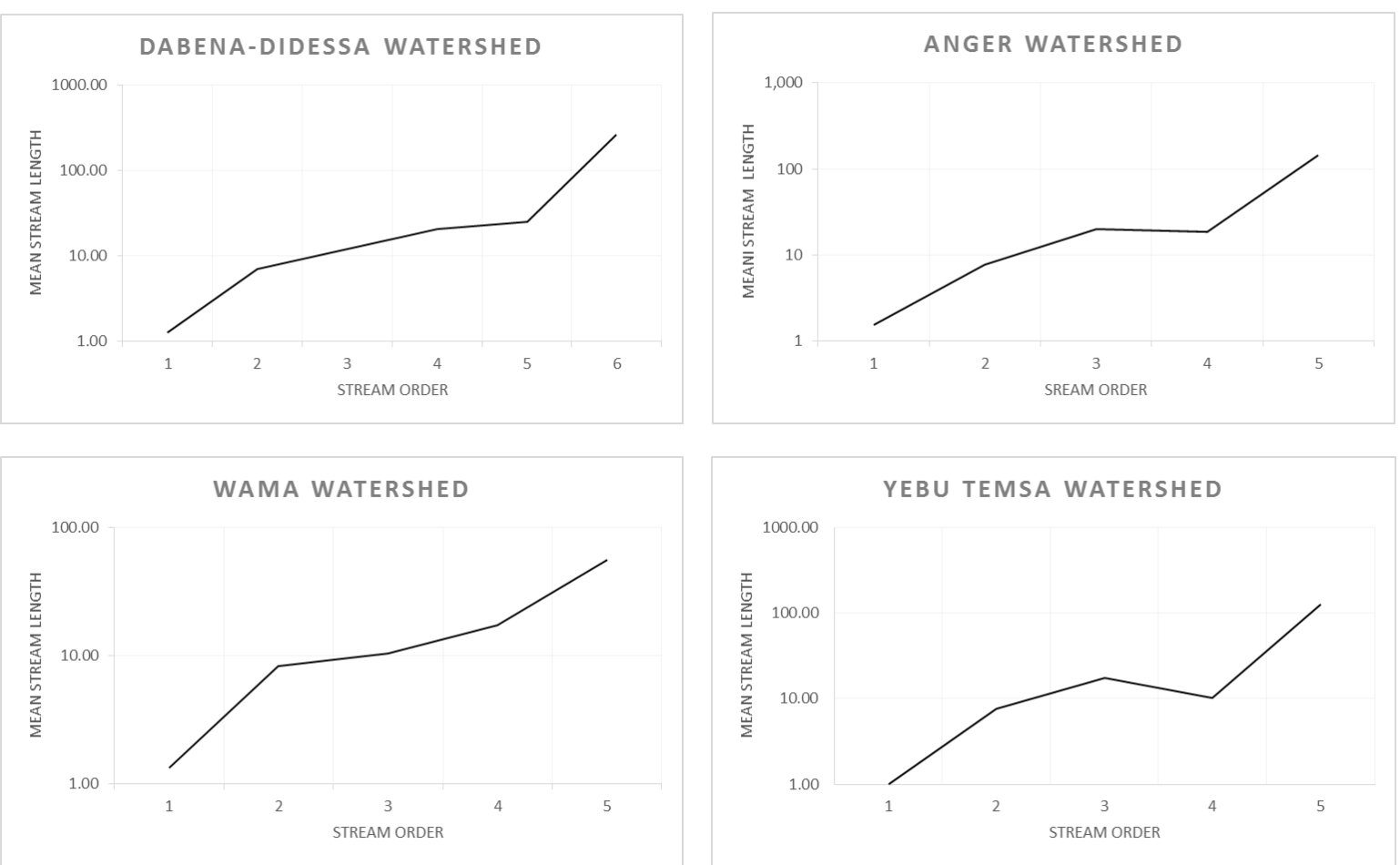

Figure 4: Log plots of stream order versus mean stream length

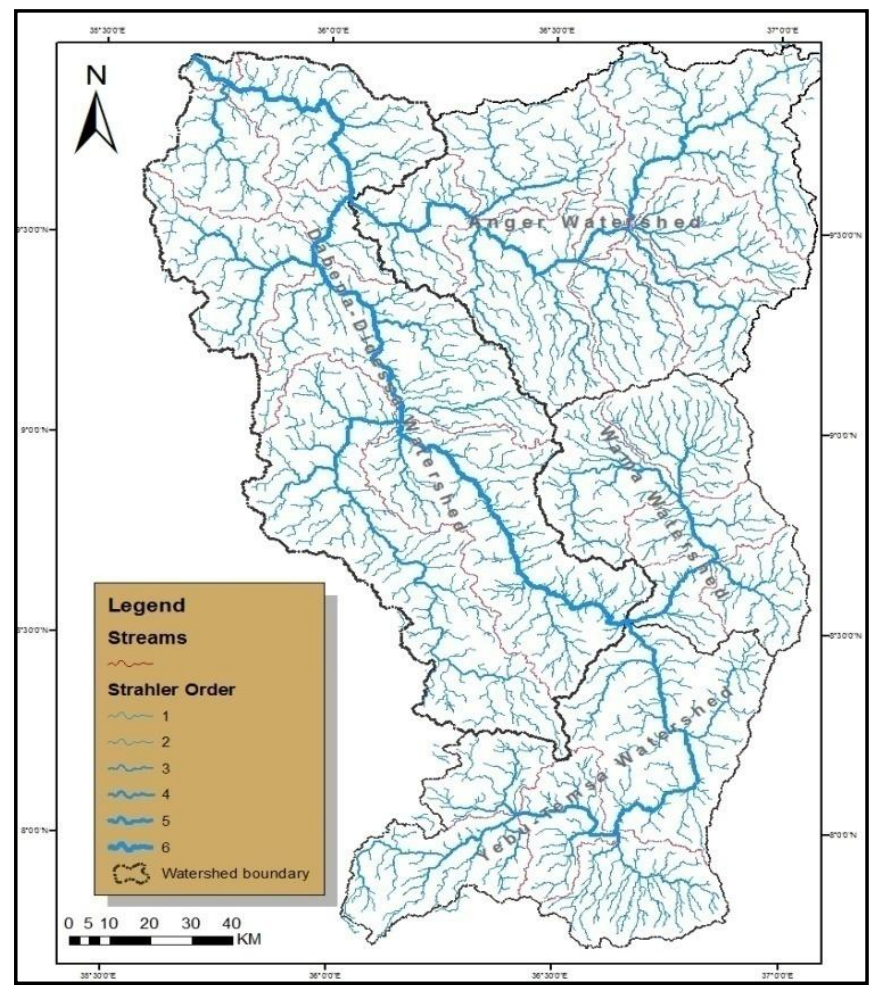

Figure 5: Drainage map of the study area 


\section{Bifurcation Ratio $\left(R_{b}\right)$}

Not only are the numbers and lengths of particular stream orders important in characterizing of stream networks, but their ratios are quite explanatory. Bifurcation ratio is the number of the segments of given order ' $N_{u}$ ' to the number of streams in the next higher order $\left(N_{u}+1\right)$. According to Horton (1945), the utility of bifurcation ratio lies in its ability to concisely express the organization of a drainage basin and level of dissection. For terrains with less dissection and minimum geological disturbance, bifurcation ratios range between 3.0 and 5.0. As shown in Table 2, mean bifurcation ratio of Yebbu-Temssa watershed is relatively higher indicating that the terrain of the basin is more dissected.

\section{ii) Basin Geometry \\ Form Factor $\left(R_{f}\right)$}

Form factor is a measure of the elongation of the basin. It is defined as the ratio of basin area to square of the basin length (Horton, 1952). As elongation increases for a given area, $R_{f}$ decreases. Among the four watersheds, Dabena-Didessa has the lowest value of $R_{f}$ implying a relatively elongated shape, while Wama Watershed is circular in shape with $R_{f}$ value of 0.67 (Table 2).

\section{Drainage Texture $\left(D_{t}\right)$}

Drainage texture refers to the relative spacing of drainage lines. It is also another indirect measure of the nature of the underlying lithology, infiltration capacity and relief aspect of the terrain. $D_{t}$ is expressed as the ratio of the total number of streams of all orders to the perimeter of the basin. According to Horton (1945) and Smith (1950), drainage texture is classified into five; very course $(<2)$, coarse $(2-4)$, moderate $(4-6)$, fine $(6-8)$, and very fine
(>8). In the present study, the drainage texture of all of the watersheds is found to be less than 2 (Table 2) which is an indicator of very course drainage texture.

\section{Stream Frequency $\left(F_{s}\right)$}

According to Horton (1945), stream frequency refers to the number of stream segments per unit area. In the present study the stream frequency shows almost positive correlation with the drainage density indicating that stream number increases with the increase in drainage density in all four watersheds (Table 2).

\section{Drainage Density $\left(D_{d}\right)$}

Drainage density is the length of streams per unit area. It indicates the level of dissection of the terrain and structure of relief. The computed drainage density in the study area is relatively higher for Wama and YebbuTemssa watersheds which are located in the upper course of the Didessa basin, indicating that the relief in these areas is higher and more dissected (Table 2).

\section{Drainage Pattern $\left(D_{p}\right)$}

Drainage pattern reflects the influence of slope, lithology and structure. According to Howard (1967), drainage pattern is related to geological information. The ratio between the number of streams and successive stream orders is indicative of drainage pattern. In a dendritic drainage pattern the number of $1^{\text {st }}$ order streams will be exactly twice that of $2^{\text {nd }}$ order streams. In a trellis network, long main stem streams are fed by many low order streams. As a result, $1^{\text {st }}$ order streams typically outnumber $2^{\text {nd }}$ order streams by 3 to 5 times. As shown in Table 1 and Fig. 6, the drainage pattern in all four watersheds is largely trellised.

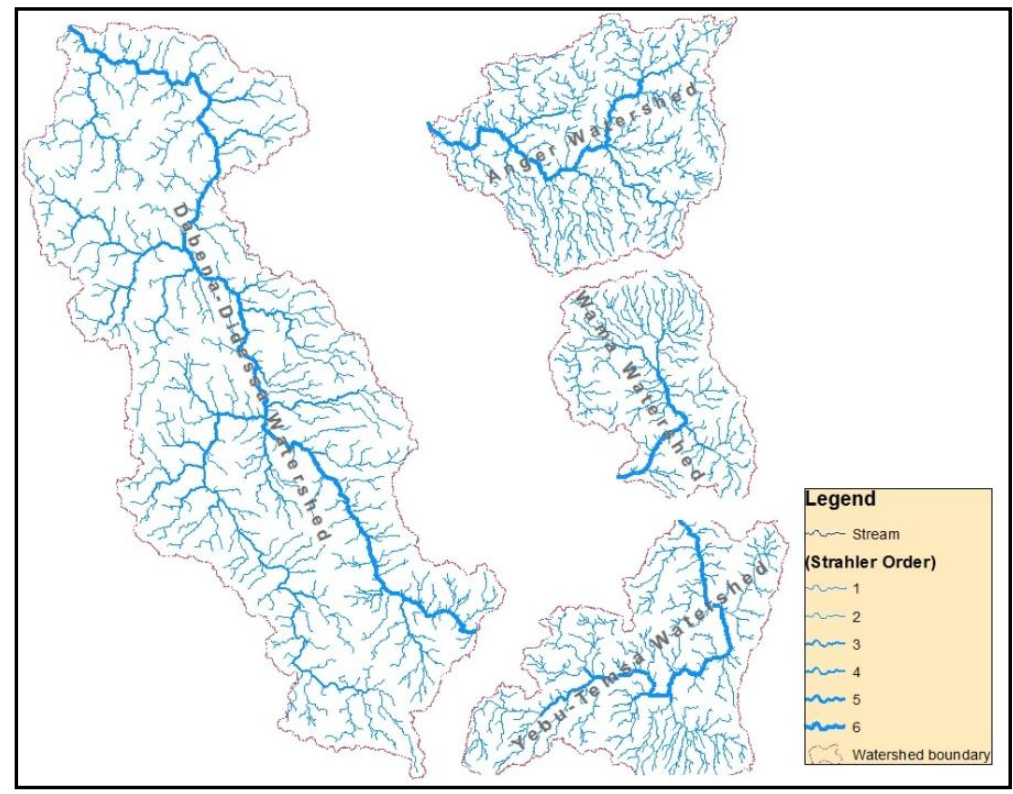

Figure 6: Map of separate watersheds

\section{Elongation Ratio $\left(R_{e}\right)$}

Elongation ratio refers to the ratio of the diameter of a circle of the same area as the drainage basin and the maximum length of the basin. Smaller value of $R_{e}$ is indicator of lower relief and elongated shape of a basin. In the study area Dabena-Didessa watershed has the lowest $R_{e}$ value implying that it is more elongated and lower in relief than the rest of the watersheds (Table 2).

\section{iii) Relief Characteristics}

Relief Ratio $\left(R_{h}\right)$

Relief also known as Height $(H)$ is calculated by determining the difference between any two elevations. Relative to a drainage basin, relief is measured by subtracting the elevation of the mouth of the basin from the highest point within the basin. Relief ratio $\left(R_{h}\right)$ is a unit 


\section{Tesfaye Muluneh and Wondimu Mamo}

less measure of the overall gradient across a basin. Calculated by dividing the relief $(H)$ of a basin by its length $\left(L_{b}\right)$, the value of relief ratio in the study area ranges between $0.01-0.03$ (Table 2). It has been observed that areas with low to moderate relief and slope are characterized by moderate value of relief ratios. Low value of relief ratios are mainly due to the resistant basement rocks of the basin and low degree of slope.

\section{Ruggedness Number $\left(R_{n}\right)$}

According to Strahler (1968) ruggedness number is a combined measure of relief and stream density. As topography becomes more convoluted, the ruggedness number increases. Calculated as multiplying the drainage
Sci. Technol. Arts Res. J., July-Sep 2014, 3(3): 191-197

density $\left(D_{d}\right)$ by basin relief $(H)$, the ruggedness number for the study area is lower (0.63) for Yebbu-Temssa watershed, and higher (0.83) for Anger watershed (Table 2). Low ruggedness value indicates gentler slope and thus less susceptible to soil erosion.

\section{Relative Relief $\left(R_{h p}\right)$}

This is the percentage relief to the perimeter of the basin and in the present study it is indicated that DabenaDidessa watershed has lower value of $R_{h p}(0.20)$, and Wama watershed with higher $R_{h p}(0.45)$ (Table 2) meaning that the slope ranges between gentle to moderately steep gradient.

Table 1: Results of morphometric parameters analysis of all watersheds

\begin{tabular}{|c|c|c|c|c|}
\hline Watershed & $\begin{array}{c}\text { Stream } \\
\text { Order } \\
\text { (Strahler) }\end{array}$ & $\begin{array}{c}\text { Total Number } \\
\text { of Streams } \\
\left(N_{u}\right)\end{array}$ & $\begin{array}{c}\text { Total Length of } \\
\text { each stream }(\mathbf{k m}) \\
\left(L_{u}\right)\end{array}$ & $\begin{array}{c}\text { Mean Stream } \\
\text { Length }(\mathbf{k m}) \\
\left(\bar{L}_{u}=\sum \frac{L_{u}}{N_{u}}\right)\end{array}$ \\
\hline \multirow{6}{*}{$\begin{array}{l}\text { Dabena - } \\
\text { Didessa }\end{array}$} & 1 & 1,473 & 1881.55 & 1.28 \\
\hline & 2 & 158 & 1122.28 & 7.10 \\
\hline & 3 & 30 & 363.76 & 12.13 \\
\hline & 4 & 7 & 145.53 & 20.79 \\
\hline & 5 & 2 & 50.03 & 25.02 \\
\hline & 6 & 1 & 263.58 & 263.58 \\
\hline \multirow{5}{*}{ Anger } & 1 & 831 & 1266.72 & 1.52 \\
\hline & 2 & 91 & 707.66 & 7.78 \\
\hline & 3 & 21 & 425.22 & 20.25 \\
\hline & 4 & 7 & 129.56 & 18.51 \\
\hline & 5 & 1 & 146.38 & 146.38 \\
\hline \multirow{5}{*}{ Wama } & 1 & 461 & 621.14 & 1.35 \\
\hline & 2 & 49 & 407.76 & 8.32 \\
\hline & 3 & 11 & 114.93 & 10.45 \\
\hline & 4 & 3 & 52.14 & 17.38 \\
\hline & 5 & 1 & 56.13 & 56.13 \\
\hline \multirow{5}{*}{$\begin{array}{l}\text { Yebbu - } \\
\text { Temssa }\end{array}$} & 1 & 986 & 976.71 & 0.99 \\
\hline & 2 & 70 & 536.58 & 7.67 \\
\hline & 3 & 13 & 225.32 & 17.33 \\
\hline & 4 & 4 & 40.54 & 10.14 \\
\hline & 5 & 1 & 126.59 & 126.59 \\
\hline
\end{tabular}

Table 2: Equations and indexes of morphometric analysis

\begin{tabular}{|c|c|c|c|c|c|}
\hline Parameters & $\begin{array}{l}\text { Symbol/ } \\
\text { Equation }\end{array}$ & $\begin{array}{c}\text { Dabena- } \\
\text { Didessa } \\
\text { Watershed }\end{array}$ & $\begin{array}{c}\text { Anger } \\
\text { Watershed }\end{array}$ & $\begin{array}{c}\text { Wama } \\
\text { Watershed }\end{array}$ & $\begin{array}{c}\text { Yebbu-Temssa } \\
\text { Watershed }\end{array}$ \\
\hline Watershed area $\left(\mathrm{km}^{2}\right)$ & $A$ & 10,963 & 7621 & 3344 & 5302 \\
\hline Watershed perimeter $(\mathrm{km})$ & $P$ & 991 & 648 & 409 & 657 \\
\hline Basin length $(\mathrm{m})$ & $L_{b}$ & 212 & 123.85 & 70.8 & 105.7 \\
\hline Drainage density & $D_{d}=\sum L_{u} / A$ & 0.35 & 0.35 & 0.37 & 0.36 \\
\hline Stream frequency & $F_{s}=\sum \frac{N_{u}}{A}$ & 0.15 & 0.12 & 0.16 & 0.20 \\
\hline Bifurcation ratio & $R_{b}=\frac{N_{u}}{N_{u}+1}$ & - & - & - & - \\
\hline $\begin{array}{l}\text { Mean Bifurcation Ratio } \\
\text { Form factor }\end{array}$ & $R_{f}=A /\left(L_{b}\right)^{2}$ & $\begin{array}{l}4.88 \\
0.24\end{array}$ & $\begin{array}{l}5.87 \\
0.50\end{array}$ & $\begin{array}{l}5.13 \\
0.67\end{array}$ & $\begin{array}{l}6.68 \\
0.47\end{array}$ \\
\hline Elongation ratio & $R_{e}=\frac{2}{\pi} \sqrt{\frac{A}{\left(L_{b}\right)^{2}}}$ & 0.31 & 0.45 & 0.52 & 0.44 \\
\hline Drainage Texture & $D_{t}=\sum N_{u} / P$ & 1.69 & 1.47 & 1.28 & 1.63 \\
\hline $\begin{array}{l}\text { Basin Relief (m) } \\
\text { Ruggedness Number }\end{array}$ & $\begin{aligned} & H=Z-z \\
R_{n}= & D_{d} \times H\end{aligned}$ & $\begin{array}{l}1975 \\
0.69\end{array}$ & $\begin{array}{r}2370 \\
0.83\end{array}$ & $\begin{array}{l}1852 \\
0.69\end{array}$ & $\begin{array}{l}1743 \\
0.63\end{array}$ \\
\hline Relief Ratio & $R_{h}=\frac{H}{L_{b}}$ & 0.01 & 0.02 & 0.03 & 0.02 \\
\hline Relative Relief & $R_{h p}=\frac{H \times 100}{P}$ & 0.20 & 0.37 & 0.45 & 0.27 \\
\hline
\end{tabular}


Tesfaye Muluneh and Wondimu Mamo

\section{CONCLUSIONS}

The study reveals that Geographic Information System (GIS) and Remote Sensing Data and techniques play a vital role for the preparation of updated drainage map and evaluation of morphometric parameters. GIS based approach facilitated analysis of different morphometric parameters, provides efficient way of handling spatial data and enhances the exploration of the relationship between drainage morphometry and several terrain attributes such as the nature of bedrock, infiltration capacity, runoff, etc. The morphometric analysis carried out by classifying the basin in to four watersheds shows that there is slight difference in their morphology and morphometric aspects. Finally, we recommend that similar studies in conjunction with high resolution elevation data should be carried out in better understanding the characteristics of river basins in the rest of Ethiopia for efficient planning and management.

\section{REFERENCES}

Bera, K. and Bandyopadhyay, J. (2013). Prioritization of Watershed using Morphometric Analysis hrough Geoinformatics technology: A case study of Dungra subwatershed, West Bengal, India. International Journal of Advances in Remote Sensing and GIS 1(3):1-8.

Chrisopher, O., Idowu, A.O. and Olugbenga, A.S. (2010). Hydrological Analysis of Onitsha North East Drainage Basin Using Geoinformatic Techniques. World Applied Sciences Journal 11(10): 1297-1302.

Gopalan, H., Whiteaker, T. and Maidment, D. (2003). Determining Watershed Parameters Using Arc Hydro. 23nd Annual Esri International User Conference. Retrieved May 15, 2014, from http://www.proceedings.esri.com/library/userconf/proc03/ p0805.pdf

Li, Z. (2014). Watershed modeling using arc hydro based on DEMs: a case study in Jackpine watershed. Environmental Systems Research 3(11): 1-12.

Lima, C.D. and CORRÊA, A.C. (2011). Analysis of the morphometric parameters of the Rio Preto basin Serra Do Espinhaco (MInas, Gerais, Brazil). UNESP, Geociências, 30(1): 105-112.

Mason, D. (2000). An Analysis of a Methodology for Generating Water Parameters using GIS. CRWR Online Report 00-3, The University of Texas, CENTER FOR
Sci. Technol. Arts Res. J., July-Sep 2014, 3(3): 191-197

RESEARCH IN WATER RESOURCES, Austin, Texas. Retrieved from http://www.crwr.utexas.edu /gis/gishydro00/library/mason/rpt00_3.pdf

Nag, S.K., and Lahiri, A. (2011). Morphometric analysis of Dwarakeswar watershed,Bankura district, West Bengal, India, using spatial information technology. International Journal of Water Resources and Environmental Engineering 3(10): 212-219.

Patino, C., McKinney, D. C., Maidment, D. R., and Whiteaker, T. (2004). Raster - Network regionalization process applied to the Rio Grande/Bravo basin. Second International Symposium on Transboundary Waters Management. Retrieved from http://citeseerx.ist.psu.edu /viewdoc/download?doi=10.1.1.399.2291 andrep=rep1 and type $=$ pdf

Pidwirny, M. (2006). "Stream Morphometry" Fundamentals of Physical Geography ( $2^{\text {nd }}$ ed.). Retrieved May 22, 2014, from http://www.physicalgeography.net/fundamentals /10ab.html

Pidwirny, M. (2006). The Drainage Basin Concept". Fundamentals of Physical Geography. Retrieved May 22, 2014, from http://www.physicalgeography.net/ fundamentals/10aa.html

Romshoo, S.A., Bhat, S.A., and Rashid, I. (2012). Geoinformatics for assessing the morphometric control on hydrological response at watershed scale in the Upper Indus Basin. Journal of Earth System Science 121(3): 659-686.

Sima, B.A. (2011). Flow Regime and Land Cover Changes In the Didessa Sub-Basin of the Blue Nile River,South Western Ethiopia: Combining Empirical Analysis and Community Perception. M.Sc Thesis, Swedish University of Agricultural Sciences, Department of Aquatic Science and Assessment, Uppsala.

Strahler, A.N. (1952). Hypsometric (Area-Altitude) Analysis of Erosional Topography. Bulletin of the Geological Society of America 63: 1117-1142.

Strahler, A.N. (1957). Quantitative Analysis of Watershed Geomorphology. Transactions, American Geophysical Union 38(6): 913-920.

Vandana, M. (2012). Morphometric analysis and watershed prioritisation: a case study of Kabani river basin, Wayand district, Kerala, India. Indian Journal of Geo-Marine Sciences 42(2): 211-222. 